\title{
Knowledge, Attitudes and Practices towards Medication Use among Health Care Students in King Saud University
}

\author{
Abdullah T. Eissa., ${ }^{1,2}$
}

\begin{abstract}
Background: Health sciences students are expected to have appropriate knowledge and attitudes toward medication use. However, literary evidence of such expertise among health sciences students of King Saud University is unknown. This study was completed to assess the knowledge about medicines and behavior of health science students towards safe use of medications. It also aims to assess the health knowledge, attitude and practices of the students. Methods: This cross-sectional study used a questionnaire consisting of 24 questions. This was administered by the researcher between October and December 2009 in the colleges of medicine, dentistry, pharmacy, applied medical science and nursing of the King Saud University. The survey consisted of three parts: Ten questions assessed the students' knowledge on drug safety (Part 1). Four questions assessed student attitude toward medication consultations by the pharmacist (Part 2) and ten questions involved medication use practices and consultation with pharmacists (Part 3). A stratified sampling method was used to select participants. Results: Pharmacy students had better medication knowledge compared to other health sciences students especially regarding antihypertensive drugs, antibiotics, paracetamol and antacids ( $p<0.05$ ). Pharmacy students showed a positive attitude regarding the trustworthiness of a pharmacist to give a consultation. Nearly all other health science students showed a negative attitude about dispensing and consultation concerning nutritional supplements by a pharmacist. All health sciences students had a similar perception toward medication use and practice. Conclusion: Pharmacy students had better knowledge about medication practice compared to other health sciences students. All other health sciences students lacked the appropriate attitude and practice related to the safe use of medications.
\end{abstract}

Key Words: Health Knowledge, Attitudes, Practice, Students, Health Occupations (Source: MeSH-NLM)

About the Author:

Abdullah Talat Eissa is a medical student at the King Saud bin Abdulaziz University For Health Sciences.
Submission: Feb 26, 2012 Accepted: Mar 1, 2013. Process: Peer-Reviewed.

\section{Introduction}

King Saud is one of the largest universities in Middle East, from which a large number of health care providers graduate. It is ranked first in the Arab and Islamic world, the Middle East and Africa, according to the international Spanish webometrics ranking system' and Academic Ranking of World Universities. ${ }^{2}$ Health sciences students' knowledge about over-the-counter prescription medications and herbal products use is very important. ${ }^{3}$

An American national survey showed that medical students have huge gaps in knowledge towards the health care system, and the students feel that these deficiencies are not appropriately treated in the medical school curriculum. ${ }^{4}$

A questionnaire-based survey for first-year medical students of the Arabian Culf University, Bahrain (including some Saudi students) suggested that these students had a poor knowledge about adequate self-medication whereas the knowledge of medication usefulness and harms was adequate. The attitude towards self-medication was positive and although the practice of self-medication was common, it was in most cases inadequate.

About $83 \%$ of American medical schools include teaching on complementary and alternative medicine in their curricula, mostly in the form of electives. ${ }^{6}$ In addition, the Centers for Disease Control and Prevention have identified that colleges and universities are essential settings to deliver health education and services.?

The growing direct-to-consumer advertising of medicinal products targets the young population, a generation exposed to large amounts of media directing them to selfmedicate. ${ }^{3}$ Lack of correct knowledge about medicines may directly lead to dangerous outcomes, such as overuse or non-compliance to treatment programs. ${ }^{8}$ For example, early self-discontinuation of antibiotics can lead to drug resis-

${ }^{1}$ College of Pharmacy, King Saud University, Riyadh, Saudi Arabia

${ }^{2}$ College of Medicine, King Saud bin Abdulaziz University For Health Sciences. 
tance and challenges to effective therapeutics for future infections.?

Health science students, including medical, dental, pharmacy and nursing students, are expected to have appropriate knowledge and attitudes toward medication use to prevent inappropriate and harmful use of the medications. For this reason, the study objective was to assess the knowledge, practice and attitude of health care students of King Saud University (KSU).

\section{Materials and Methods}

This cross-sectional study utilized a structured, self-administrated questionnaire that intended to evaluate the knowledge and behavior of medical, dental, pharmacy and nursing students at King Saud University toward common medication in Saudi Arabia. The survey was validated to ensure clear questions and simple and comprehensible language.

The questionnaire was distributed in paper and electronic format and was divided in three parts. (1) Questions to evaluate health science students' knowledge of drug safety, (2) questions to assess students' attitude toward medication consultations by the pharmacist, and (3) questions to identify medication use practices and consultation with pharmacists.

Part one utilized true and false questions to assess drug safety knowledge in five critical areas in our country: (1) anti-hypertensive drugs and regimens, (2) antibiotic use, (3) antacid use, (6) medication storage, and (7) vitamins, non-prescription drugs and herbal product use.

Part two included the items of the attitude assessment that were four questions answered to indicate how students trust pharmacists regarding the consulting and dispensing of medications, herbals and food. Items were scored on a five-point Likert scale, where higher scores indicated more positive attitudes toward medication consultation provided by pharmacists.

Part three included ten items of the practice questionnaire that were divided into three subscales: two items on selfcare management, four items on appropriate use, and four items on prescription filling and medication consultation with a pharmacist. Items were scored on a five-point Likert scale. The coding for medication consultation with a pharmacist was the reverse, where (1) was never, (2) seldom, (3) sometimes, (4) usually, and (5) always. A higher total score represented better practices associated with safer medication use.
Table 1. Distribution of pharmacy, nursing applied medical science, medical, and dentistry students in self-administered questionnaire by percent and frequency.

\begin{tabular}{|c|c|c|}
\hline Students & Percent & Frequency \\
\hline Pharmacy students & $37.3 \%$ & 76 \\
\hline Nursing students & $15.2 \%$ & 31 \\
\hline Applied medical science students & $18.1 \%$ & 37 \\
\hline Medical students & $27.5 \%$ & 56 \\
\hline Dentistry students & $2.0 \%$ & 4 \\
\hline Total & $100.0 \%$ & 204 \\
\hline Pharmacy students & $37.3 \%$ & 76 \\
\hline Non-pharmacy health students & $62.7 \%$ & 128 \\
\hline
\end{tabular}

An overall internal consistency reliability coefficient (Spearman's rho) was calculated for the questionnaire. Respondents were classified into two groups, which included the pharmacy students and other health students.

\section{Results}

of 450 surveys distributed to five different health college students of King Saud University, including the colleges of medicine, pharmacy, nursing, applied medical science, and dentistry, 204 surveys were completed and returned to the researcher. Table 1 shows the distribution of respondents among different health students to compare the responses of $76(37.3 \%)$ pharmacy students with $128(62.7 \%)$ other health sciences students which includes $56(27.5 \%)$ medical students, 31 (15.2\%) nursing students, 37 (18.1\%) applied medical science students and 4 (2.0\%) dentistry students. Table 2 shows health sciences students' responses to questions regarding knowledge of medication use. Although pharmacy students had better knowledge about medication use in the majority of the questions, the main difference between both groups was knowledge about antihypertensive drugs, antibiotics, paracetamol, antacids and drug interactions $(p<0.05)$. In the question relating to the antihypertensive medication, pharmacy students performed significantly better than other colleges $(p=0.000)$. In the question relating to the antibiotics, pharmacy students demonstrated a significantly higher level of knowledge compared to other health college students $(p=0.013)$. In addition, the question regarding the toxicity of paracetamol and antacids and the interference of drugs with other substances showed significant differences between the two groups $(p=0.013, p=0.000, p=0.000$, respectively). In the remaining questions, which were related to antacid administration, vitamins, storing of ointment, storing of syrup and dosage of cough syrup, there were no significant differences between the two groups. 
Table 2: Responses of pharmacy, nursing, applied medical science, medical, and dentistry students regarding knowledge of medication use by percent and frequency $(\mathrm{N}=204)$

\begin{tabular}{|c|c|c|c|c|c|}
\hline \multirow{2}{*}{ Question } & \multicolumn{2}{|c|}{ Pharmacy students } & \multicolumn{2}{|c|}{$\begin{array}{l}\text { Other health } \\
\text { students }\end{array}$} & \multirow{2}{*}{$\begin{array}{l}\mathrm{P} \\
\text { value }\end{array}$} \\
\hline & True & False & True & False & \\
\hline $\begin{array}{l}1 \text {-Antihypertensive drugs } \\
\text { could be discontinued when } \\
\text { blood pressure returns to a } \\
\text { normal range. }\end{array}$ & $\begin{array}{c}10 \\
(13.2 \%)\end{array}$ & $\begin{array}{c}66 \\
(86.8 \%)\end{array}$ & $\begin{array}{c}50 \\
(40.7 \%)\end{array}$ & $\begin{array}{c}73 \\
(59.3 \%)\end{array}$ & 0.000 \\
\hline $\begin{array}{l}2 \text { - You can discontinue the } \\
\text { use of antibiotics by yourself } \\
\text { when the symptoms of fever } \\
\text { or sore throat are relieved. }\end{array}$ & $\begin{array}{c}5 \\
(6.6 \%)\end{array}$ & $\begin{array}{c}71 \\
(93.4 \%)\end{array}$ & $\begin{array}{c}25 \\
(19.7 \%)\end{array}$ & $\begin{array}{c}102 \\
(80.3 \%)\end{array}$ & 0.013 \\
\hline $\begin{array}{l}3 \text { - overdose of Panadol } ® \\
\text { (acetaminophen) will cause } \\
\text { liver toxicity. }\end{array}$ & $\begin{array}{c}69 \\
(90.8 \%)\end{array}$ & $\left(\begin{array}{c}7 \\
(9.2 \%)\end{array}\right.$ & $\begin{array}{c}96 \\
(76.8 \%)\end{array}$ & $\begin{array}{c}29 \\
(23.2 \%)\end{array}$ & 0.013 \\
\hline $\begin{array}{l}4 \text { - Antacids should be } \\
\text { chewed before swallowing to } \\
\text { achieve a better effect. }\end{array}$ & $\begin{array}{c}35 \\
(46.1 \%)\end{array}$ & $\begin{array}{c}41 \\
(53.9 \%)\end{array}$ & $\begin{array}{c}49 \\
(40.2 \%)\end{array}$ & $\begin{array}{c}73 \\
(59.8 \%)\end{array}$ & 0.461 \\
\hline $\begin{array}{l}5 \text { - Antacids should be added } \\
\text { into all prescriptions to avoid } \\
\text { CI upset. }\end{array}$ & $\begin{array}{c}7 \\
(9.2 \%)\end{array}$ & $\begin{array}{c}69 \\
(90.8 \%)\end{array}$ & $\begin{array}{c}44 \\
(35.5 \% s)\end{array}$ & $\begin{array}{c}80 \\
(64.5 \%)\end{array}$ & 0.000 \\
\hline $\begin{array}{l}6 \text { - Vitamins are a health } \\
\text { food, so overusing them will } \\
\text { not cause negative effects to } \\
\text { the human body. }\end{array}$ & $13(17.3 \%)$ & $\begin{array}{c}62 \\
(82.7 \%)\end{array}$ & $\begin{array}{c}31 \\
(24.2 \%)\end{array}$ & $\begin{array}{c}97 \\
(75.8 \%)\end{array}$ & 0.292 \\
\hline $\begin{array}{l}7 \text { - Storing ointment or gel in } \\
\text { the refrigerator could extend } \\
\text { the expiration date. }\end{array}$ & $\begin{array}{c}28 \\
(36.8 \%)\end{array}$ & $\begin{array}{c}48 \\
(63.2 \%)\end{array}$ & $\begin{array}{c}43 \\
(35.0 \%)\end{array}$ & $\begin{array}{c}80 \\
(65.0 \%)\end{array}$ & 0.879 \\
\hline $\begin{array}{l}8 \text { - Storing syrup in the } \\
\text { refrigerator could extend the } \\
\text { expiration date. }\end{array}$ & $\begin{array}{c}30 \\
(39.5)\end{array}$ & $\begin{array}{c}46 \\
(60.5 \%)\end{array}$ & $\begin{array}{c}39 \\
(31.5 \%)\end{array}$ & $\begin{array}{c}85 \\
(68.5 \%)\end{array}$ & 0.284 \\
\hline $\begin{array}{l}9 \text { - Dosage of cough syrup is } \\
\text { one bottle per use. }\end{array}$ & $20(26.3)$ & $\begin{array}{c}56 \\
(73.7 \%)\end{array}$ & $\begin{array}{c}34 \\
(27.4 \%)\end{array}$ & $\begin{array}{c}90 \\
(72.6 \%)\end{array}$ & 0.872 \\
\hline $\begin{array}{l}10 \text { - Taking some medicines } \\
\text { with food, drink or tea will } \\
\text { interfere with the effect of } \\
\text { medicine. }\end{array}$ & $70(92.1 \%)$ & $\begin{array}{c}6 \\
(7.9 \%)\end{array}$ & $\begin{array}{c}86 \\
(69.4 \%)\end{array}$ & $\begin{array}{c}34 \\
(27.4 \%)\end{array}$ & 0.000 \\
\hline
\end{tabular}

Table 3 shows health college students' attitudes toward medication consultation with a pharmacist. Pharmacy students showed a positive attitude and agreed with the perception that a pharmacist is a trusted person to provide consultation about drugs while other health sciences students tended to neither agree nor disagree. Regarding dispensing medication and consultation by a pharmacist, other health sciences students showed negative attitudes, while pharmacy students did not. Other health sciences students also showed negative attitudes regarding herbal medicine consultation by pharmacists. Both pharmacist and other health sciences students showed negative attitudes about dispensing and consultation of nutritional supplements by the pharmacist.

Table 4 shows medication use and practice among pharmacy and health sciences college students. Both pharmacy students and other health sciences students had the same practice level toward seeking non-prescription medications from community pharmacies, giving prescription medicine to others and combining herbal medication with
Table 3. Attitudes of pharmacy, nursing, applied medical science, medical, and dentistry by mean and standard deviation towards medication consultation by pharmacists $(\mathrm{N}=204)$.

\begin{tabular}{|c|c|c|}
\hline Question & $\begin{array}{l}\text { Pharmacy } \\
\text { students } \\
\text { Mean (SD) }\end{array}$ & $\begin{array}{l}\text { Other health } \\
\text { students } \\
\text { Mean (SD) }\end{array}$ \\
\hline $\begin{array}{l}1 \text {-Do you trust the pharmacist as } \\
\text { a consultant of drug information? }\end{array}$ & $4.1(1.1)$ & $3.2(1.1)$ \\
\hline $\begin{array}{l}2 \text { - Is there a need to consult a } \\
\text { pharmacist for dispensing and } \\
\text { using medications? }\end{array}$ & $4.0(1.1)$ & $2.9(1.0)$ \\
\hline $\begin{array}{l}3 \text { - Is there a need to consult a } \\
\text { pharmacist for dispensing and } \\
\text { using herbal medicines? }\end{array}$ & $3.5(1.2)$ & $2.8(1.1)$ \\
\hline $\begin{array}{l}4 \text { - Is there a need to consult a } \\
\text { pharmacist for dispensing and } \\
\text { using healthy food? }\end{array}$ & $2.8(1.1)$ & $2.7(1.2)$ \\
\hline
\end{tabular}

Legend: (1) always, (2) usually, (3) sometimes, (4) seldom, and (5) never.

Table 4. Medication use or practice among pharmacy and other health college students.

\begin{tabular}{|c|c|c|}
\hline Question & $\begin{array}{l}\text { Pharmacy } \\
\text { students } \\
\text { Mean }\end{array}$ & $\begin{array}{l}\text { Other } \\
\text { health } \\
\text { students } \\
\text { Mean }\end{array}$ \\
\hline $\begin{array}{l}1 \text { - When you have a cold, will you } \\
\text { seek non-prescription medicine in the } \\
\text { community pharmacy? }\end{array}$ & $2.1(0.9)$ & $2.8(1.3)$ \\
\hline $\begin{array}{l}2 \text { - When you have a cold, will you ask } \\
\text { a community pharmacist for medication } \\
\text { without a prescription? }\end{array}$ & $2.2(1.0)$ & $2.8(1.3)$ \\
\hline $\begin{array}{l}\text { 3- Have you ever given your prescription } \\
\text { medicines to others? }\end{array}$ & $4.0(1.2)$ & $3.6(11.3)$ \\
\hline $\begin{array}{l}4 \text { - Will you combine herbal medicine } \\
\text { when you take usual medicine? }\end{array}$ & $4.0(1.0)$ & $3.8(1.2)$ \\
\hline $\begin{array}{l}5 \text { - Will you try medicines according to } \\
\text { your friend's suggestion? }\end{array}$ & $4.1(0.9)$ & $3.7(1.2)$ \\
\hline $\begin{array}{l}6 \text { - When your symptoms are relieved, } \\
\text { will you discontinue your prescription } \\
\text { medicine by yourself? }\end{array}$ & $3.7(1.3)$ & $3.1(1.3)$ \\
\hline $\begin{array}{l}7 \text { - Did you ever receive your prescription } \\
\text { from a hospital and have it dispensed in } \\
\text { the community pharmacy? }\end{array}$ & $2.9(1.2)$ & $3.0(1.2)$ \\
\hline $\begin{array}{l}8 \text { - Will you consult your pharmacist } \\
\text { when you receive a special or uncommon } \\
\text { dosage form of medicine (eg. nasal spray } \\
\text { or suppository)? }\end{array}$ & $2.4(1.1)$ & $3.0(1.1)$ \\
\hline $\begin{array}{l}9 \text { - When you visit your pharmacist, } \\
\text { will you bring all medications you are } \\
\text { currently taking? }\end{array}$ & $3.4(1.4)$ & $3.3(1.4)$ \\
\hline $\begin{array}{l}10 \text { - Will you check with your pharmacist } \\
\text { before taking medicines that you have } \\
\text { never used before? }\end{array}$ & $2.7(1.4)$ & $2.9(1.3)$ \\
\hline
\end{tabular}

Legend: (1) always, (2) usually, (3) sometimes, (4) seldom, and (5) never.

prescription medicine. Other related questions provided similar responses between both groups.

\section{Discussion}

Pharmacy students demonstrated higher levels of knowledge about medication practices compared to other health sciences students according to the significance of the results of many questions. Results shown in Table 2 suggest that patients should seek the appropriate management from licensed physicians or pharmacists. Despite the fact that nurses, dentists, and applied science specialists are 
considered health care providers, they cannot prescribe and consult patients regarding medication-related concerns. In addition, Table 2 suggests that the curricula of these health colleges does not provide appropriate teaching of pharmacology. Undergraduate pharmacy students seem to still be unable to deal with all medications appropriately because there were some questions that were not solved correctly by the majority of them. Dental students' responses suggested little knowledge about the items of the questionnaire, leading them to be classified similarly to the general public.

Table 3 shows that other health college students express neutral responses when asked about the perceived need to consult a pharmacist to adequately use and dispense medications, herbals, and food products. This is considered an inappropriate attitude because the use of medications, herbals, and food products to some extent is considered to fall under the responsibilities of pharmacists. Pharmacy college students agreed that the pharmacists are knowledgeable and can dispense drugs but the students lacked an appropriate attitude towards consulting pharmacists for the use of herbal and food products.

Table 4 shows that both pharmacy students and other health students lacked appropriate practices related to the safe use of medications. That may be because the curricula emphasize gaining knowledge more than clinical practice. Further training and interventions are warranted to improve the attitude and practice related to the safe use of medications in both student groups.

\section{References}

1. Ranking Web of World Universities [internet]. 2010 [cited2010 July] Available from: http://www.webometrics.info/top12000.asp.

2. Academic Ranking of World Universities [internet]. 2010[cited 2010]. Available from: http://www.arwu.org/ARWU2010.jsp\#.

3. Hsio F, Lee J, Huang W, Chen S, Chen H. Survey of medication knowledge and behaviors among college students in Taiwan. Am J Pharm Educ 2006;70(2):30. 4. Agrawal J, Huebner J, Hedgecock J et al. Medical Students' Knowledge of the U.S. Health Care System and Their Preferences for Curricular Change: A National Survey Academic Medicine. Academic Medicine 2005;80(5); 484-488 5. James H, Handu SS, Al Khaja KA, Otoom S, Sequeira RP. Evaluation of the knowledge, attitude and practice of self-medication among first-year medical students. Med Princ Pract 2006;15(4):270-5

6. Halterman-Cox M, Sierpina V, Sadoski M, Sanders C. CAM Attitudes in first- and second-year medical students: A pre- and post-course survey. Integrative Medicine 2009;7(6):34-42.

7. Centers for Disease Control and Prevention. Youth risk behavior surveillance: National College health risk behavior survey - United States. MMWR. 1997;46(SS-6):1-54.

8. Azmi M, Hassali A, Stewart K, Kong D. A national survey on knowledge and perceptions of senior medical students in Australia about generic medicines. Med J Aust 2008;188(2):120-128.

Acknowledgements

Thanks to Mansour Adam for his advice.

Conflict of Interest Statement at Funding

The Authors have no funding, financial relationships or conflicts of interest to disclose.

Cite as:

Eissa AT. Knowledge, attitudes and practices towards medication use among health care students in King Saud University. Int J Med Students 2013;1(2):66-9. 